\title{
En ung mann med svelgevansker
}

\author{
Sår hals og svelgevansker er vanlige symptomer i allmennpraksis. \\ De skyldes ofte virusinfeksjon og krever som regel ikke behandling. \\ Men disse symptomene kan en sjelden gang være tegn på en tilstand \\ som raskt kan utvikle seg til å bli livstruende.
}

Se kommentar side 1244

\section{Rebecca Bhatti \\ Allmennlegevakten \\ Legevakten i Oslo}

\section{Tone Solvik-Olsen}

Barnemedisinsk avdeling

Sykehuset Telemark Skien

Karl Fredrik Nordfalk

$\emptyset$ re-nese-hals-avdelingen

Oslo universitetssykehus, Rikshospitalet

\section{Odd Martin Vallersnes}

odd-martin.vallersnes@lva.oslo.kommune.no Allmennlegevakten

Legevakten i Oslo

og

Avdeling for allmennmedisin

Universitetet i Oslo

En mann i 30-årene oppsøkte legevakten etter å ha hatt vondt $i$ halsen $i$ om lag ett døgn. Noen timer før han kom hadde han fått svelgevansker og problemer med å svelge sitt eget spytt. Svelgevanskene kom mens han spiste et rekesmørbrød. Han ble innskrevet kl 2245 og straks vurdert av sykepleier. Han hadde da en puls på $113 \mathrm{slag} / \mathrm{min}$ og oksygenmetning på $98 \%$ og klarte å drikke vann. Etter en snau times venting, kl 2333, ble han tilsett av lege.

Pasienten var tidligere frisk, brukte ingen medisiner fast og hadde ingen kjente allergier. Han antok at han hadde fulgt de vanlige vaksinasjonsprogrammene. Han røykte ikke og drakk alkohol kun ved festlige anledninger. Pasienten følte selv at lymfeknutene på halsen hadde hovnet opp. Han hadde ikke feberfølelse eller kløe, hadde ikke kastet opp eller observert hudutslett. Han var sikker på at han ikke hadde spist noe han aldri hadde spist før. Han mente også at det ikke var noe i maten som kunne ha satt seg fast $i$ halsen.

Ved den kliniske undersøkelsen var han i god allmenntilstand og gjorde godt rede for seg. Han var tørr og varm $i$ huden, litt hes $i$ stemmen og hadde økt respirasjonsfrekvens på 20/min. Blodtrykket var 163/119 mm Hg, pulsen regelmessig $113 \mathrm{slag} / \mathrm{min}$, temperaturen $37,2^{\circ} \mathrm{C}$ og oksygenmetningen $99 \%$ uten oksygentilførsel. Han hadde ingen stridor. Det var minimal rubor i svelget, og tonsillene var normale. Det var ingen hevelse i tungen, drøvelen eller på leppene. På halsen var det en palpabel, liten lymfeknute på venstre side. Over lungene var det normale respirasjonslyder og ikke forlenget ekspirium eller pipelyder. For øvrig var det normale funn ved klinisk undersøkelse. Kapillær CRP var $32 \mathrm{mg} / \mathrm{l}$ (< $10 \mathrm{mg} / \mathrm{ll}$, og hurtigtest på streptokokker gruppe $A$ var negativ.

På grunn av kort sykehistorie, ingen uttalt glandelsvulst på halsen og beskjedne funn i svelget lot man være å ta en hurtigtest på mononukleose. Undersøkende lege vurderte muligheten for allergisk reaksjon i kombinasjon med en viral luftveisinfeksjon. Det var allikevel et noe avvikende klinisk bilde, med tanke på at pasienten hadde forhøyet respirasjonsfrekvens, men verken synlige hevelser, kløe eller utslett. Det kliniske bildet passet ikke helt med noen av de årsakene til svelgevansker som en legevaktlege til vanlig ser hos yngre pasienter, som viral faryngitt, bakteriell tonsillitt, mononukleose, allergisk reaksjon og fremmedlegeme $i$ halsen. Undersøkende lege valgte derfor å tilkalle en kollega for å få en ny vurdering.

Etter å ha undersøkt pasienten var kollegaen enig $i$ at sykehistorien og funnene ikke helt stemte med tilstandene nevnt over. Man valgte allikevel å gi behandling for allergisk reaksjon med 0,2 $\mathrm{mg}$ adrenalin subkutant, som ble gjentatt én gang, 100 mg hydrokortison intravenøst og $5 \mathrm{mg}$ deksklorfeniramin intravenøst. Pasienten merket ingen bedring av dette.

Da det var gått om lag 40 minutter etter første legetilsyn, ble han i løpet av kort tid respiratorisk besværet. Han ble hesere og fikk etter hvert inspiratorisk stridor og økende respirasjonsfrekvens. Han var fortsatt tørr og varm i huden, hadde ingen cyanose, og oksygenmetningen var $98 \%$. Han begynte à spytte ut slim og syntes det var tiltakende vanskelig å svelge sitt eget spytt. Han fikk 4 l oksygen på nesegrime.
Grunnet manglende behandlingsrespons var det fremdeles usikkerhet rundt diagnosen, og sjeldnere tilstander ble vurdert. Det kliniske bildet forverret seg raskt - pasienten hadde utviklet inspiratorisk stridor. Dette er tegn på obstruksjon av de øvre luftveiene og kan blant annet ses ved falsk krupp (laryngitt), ekte krupp (difteri), epiglottitt og fremmedlegeme i de øvre luftveiene (1).

Laryngitt (falsk krupp) er en vanlig tilstand hos barn, men ses nesten aldri hos voksne grunnet anatomiske forhold. Difteri (ekte krupp), som er forårsaket av bakterien Corynebacterium diphteriae og dens toksin, gir som oftest en akutt infeksjon i slimhinnene i svelg og luftveier og kan gi hevelse som blokkerer luftveiene. Etter at vaksinasjon ble innført i 1952 er difteri en svært sjelden sykdom i Norge (2). Epiglottitt er en sjelden og alvorlig tilstand og kan være forårsaket av Hemophilus influenzae type B (Hib). Vaksinasjon mot Hib ble innført i barnevaksinasjonsprogrammet i 1992 (3). Vår pasient var ikke vaksinert.

Muligheten for at pustevanskene skrev seg fra patologiske forhold i lungene ble vurdert, men sykehistorien tilsa at problemet satt i svelget, og det var ikke andre funn over lungene enn inspiratorisk stridorlyd. Legevaktlegene besluttet å konferere med vakthavende øre-nese-hals-lege ved universitetssykehuset, og man ble enige om innleggelse, da pasienten var blitt klart mer besværet på kort tid.

Kl 0030 ble det bestilt ambulanse, kode rød (raskeste respons). Ambulansen var ved legevakten kl 0034, dro derfra kl 0039 og ankom akuttmottaket ved universitetssykehuset $k l$ 0046. Ett til to minutter før ankomst falt oksygenmetningen og pasienten ble cyanotisk. Ambulansepersonellet startet maskeventilering, noe som var vanskelig på grunn av kramper og uro. Ved ankomst til universitetssykehuset var pasienten bevisstløs og hadde kramper. Han var tydelig cyanotisk, hadde en oksygenmetning på $30-40 \%$ og en puls på $30 \mathrm{slag} / \mathrm{min}$. Det ble gitt atropin og diazepam. Pasienten ble ventilert på maske, og oksygenmetningen steg til $90 \%$, men situasjonen var fortsatt ustabil.

Anestesilege utførte laryngoskopi, men intubasjon var ikke mulig på grunn av hevelse i epiglottis. Øre-nese-hals-legen forsøkte å intubere via skop, men dette var heller ikke mulig. Han valgte da å nødtrakeotomere pasienten med et ferdigmontert koniotomisett gjennom membrana cricothyreoidea. Pasien- 
ten fikk etter dette tilfredsstillende oksygenmetning. Det ble anlagt arteriekran, og blodgass viste $\mathrm{pH}$ 6,6 (7,35-7,43), $\mathrm{pCO}_{2}$ $16 \mathrm{kPa}(4,7-5,9 \mathrm{kPa})$ og laktat $21 \mathrm{mmol} / \mathrm{l}$ (0,8-2,8 $\mathrm{mmol} / \mathrm{l})$. Det ble deretter lagt en konvensjonell trakeostomi i operasjonsavdelingen, og pasienten ble flyttet til intensivavdelingen for videre observasjon.

Ny blodgass viste bedring av verdiene. Det ble tatt blodkulturer før oppstart av antibiotika, cefotaksim $2 \mathrm{~g}$ intravenøst fire ganger $\mathrm{i}$ døgnet. Blodprøver viste $\mathrm{Hb} 12,4 \mathrm{~g} / 100 \mathrm{ml}$ $(13,2-16,6 \mathrm{~g} / 100 \mathrm{ml})$, leukocytter $17,5 \cdot 10^{9} / \mathrm{l}$ (4,0-11,0 $\cdot 10^{9} / \mathrm{ll}, \mathrm{CRP} 28 \mathrm{mg} / \mathrm{l} /<5 \mathrm{mg} / \mathrm{ll}$. Det var ingen oppvekst i blodkultur og heller ikke i prøve tatt direkte fra epiglottis.

Den første blodgassen viste en kombinasjon av respiratorisk og metabolsk acidose. Luftveisobstruksjon gir respiratorisk acidose, fordi kroppen ikke får skilt ut karbondioksid. Luftveisobstruksjon medfører også hypoksi, og hypoksien fører til anaerob metabolisme og laktatdanning og dermed metabolsk acidose. CRP og leukocytter er som oftest forhøyet ved epiglottitt, som hos vår pasient, men ikke alltid $(4,5)$.

Det var ingen oppvekst i de mikrobiologiske prøvene, noe som er vanlig ved epiglottitt, uvisst av hvilken årsak. I flere studier har flertallet av pasientene negative blodkulturer, i enkelte opp mot $80 \%$ (4-7). Der agens lot seg påvise, var Hib fortsatt utbredt blant uvaksinerte voksne i amerikanske studier fra 1990-årene $(4,7)$. Nyere nordiske studier viser økende forekomst av streptokokker, men Hib påvises sjelden (5, $6,8)$.

Pasienten ble observert $i$ intensivavdelingen i halvannet døgn og var sedert med propofol og fentanyl. Deretter ble han flyttet til vanlig sengepost og var da i god allmenntilstand. Det tredje døgnet ble trakealkanylen seponert, og trakeostomien ble dekket med tape. Pasienten ble gradvis bedre og kunne etter hvert spise vanlig mat. Han ble utskrevet den åttende dagen etter innkomst med videre peroral behandling med cefaleksin mikstur.

Ved kontroll på øre-nese-hals-poliklinikken 24 dager etter inngrepet var det fin lukking av trakeostomien. Det var vedvarende lett ødem i epiglottis, og pasienten måtte av og til svelge vann for å få ned matbiter. Man valgte derfor å gi ham en ny kur med cefaleksin tabletter. Ved ny kontroll 45 dager etter inngrepet hadde han ingen plager, bortsett fra en liten utposning kranialt for trakeostomiarret. Undersøkelse med fleksibelt skop viste helt upåfallende epiglottis og omkringliggende strukturer.

\section{Diskusjon}

Epiglottitt er en infeksjon i epiglottis. Hos barn gir dette en lokalisert hevelse i epiglottis, mens man hos voksne ofte ser en mer diffus inflammasjon med affeksjon også av de supraglottiske strukturene $(4,5)$. Det er en

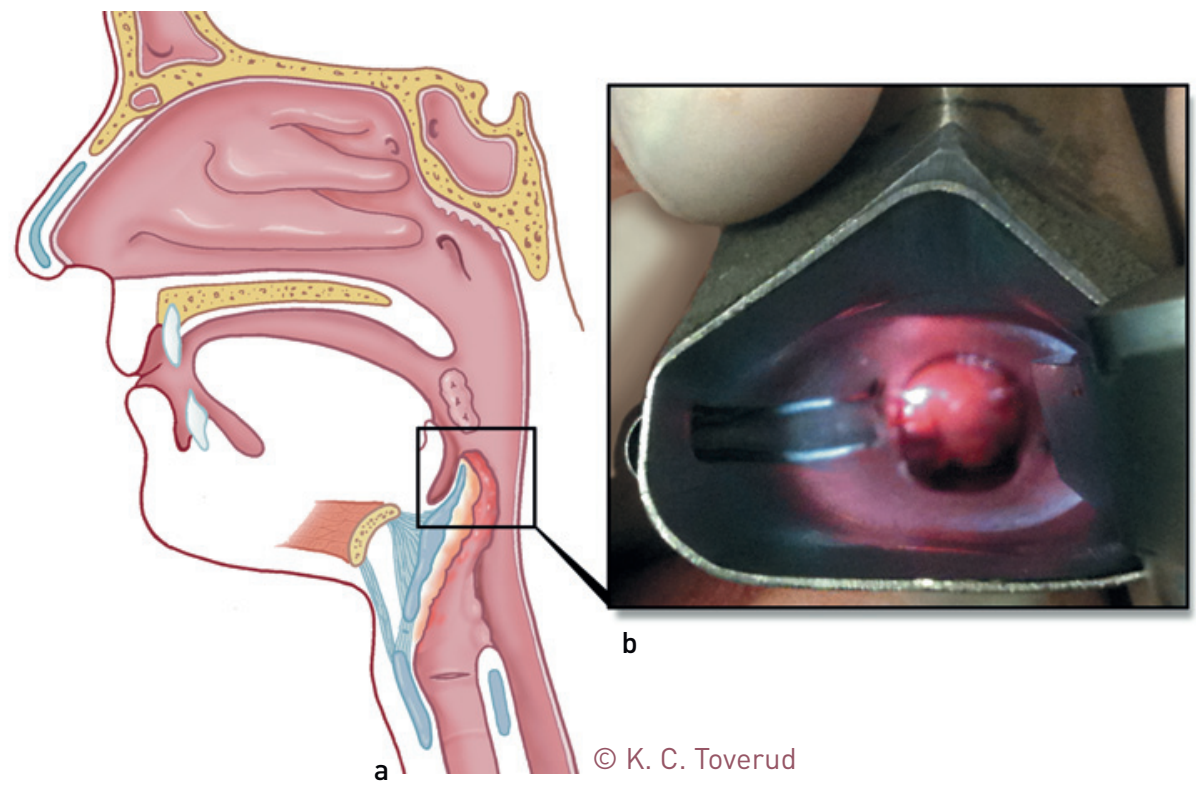

a) Sagittalt snitt gjennom hode og hals med hevelse i epiglottis. b) Fotografi av hevelsen i epiglottis (fra øre-nesehals-legens undersøkelse)

potensielt livstruende tilstand, som raskt kan utvikle seg til en øvre luftsveisobstruksjon. Etter at vaksinasjon mot Hib ble innført, har insidensen hos barn falt dramatisk, og epiglottitt ses nå nærmest utelukkende hos voksne $(4,6)$. Imidlertid er det vist at vaksinesvikt forekommer (9). I en svensk studie fra 1993-2008 fant man en insidens på 0,51/ 100000 innbyggere per år i aldersgruppen $0-14$ år og på 1,1/100 000 innbyggere per år for dem over 14 år (6). Studier fra Island (8) og Finland (5) har vist at insidensen hos voksne varierer fra $0,93 / 100000$ til 4,73/100 000 innbyggere per år. I flere studier er det vist økning i insidensen blant voksne $(4,5$, 8 ). Det kan blant annet skyldes bedre diagnostiske metoder, som bruk av fleksibelt laryngoskop $(5,8)$. I den tidligere refererte svenske studien ble det derimot rapportert synkende insidens (6).

De vanligste symptomene hos voksne pasienter med epiglottitt er sår hals og svelgevansker. Andre symptomer og kliniske funn kan være heshet, hoste, endret stemme, ømhet over tungebeinet og problemer med å svelge spyttet. Ofte er det lite eller ingen feber $(4,7,10)$. Respiratorisk besvær med økt respirasjonsfrekvens, det at pasienten må sitte i oppreist stilling, stridor og sikling indikerer et mer alvorlig forløp $(4,7)$. Man må være spesielt oppmerksom på pasienter med kort sykehistorie og rask utvikling av symptomene (4). I et tidlig stadium eller i et mildt forløp kan det være vanskelig å skille epiglottitt fra faryngitt, mononukleose, lingval tonsillitt, peritonsillær abscess, difteri, Ludwigs angina og laryngitt. Andre ikkeinfeksiøse tilstander som kan gi sår hals og svelgevansker er angioødem, gastroøsofageal refluks, tumor, traume, kjemisk irritasjon og fremmedlegeme (11).

Mistanke om epiglottitt skal vekkes ved uttalte svelgevansker med sparsomme funn i svelget og ved kombinasjonen svelgevansker og stridor. Diagnosen stilles ved visualisering av epiglottis ved hjelp av et fleksibelt laryngoskop. Dersom laryngoskop ikke er tilgjengelig, kan man undersøke pasienten med et lett oppvarmet larynxspeil samtidig som man forsiktig holder i tungen med en kompress. Anestesiberedskap bør være tilgjengelig før man begynner med noen av disse undersøkelsene, da manipulering av epiglottis kan utløse spasme i luftveiene og dermed raskt forverre situasjonen.

Ved behandling bør man velge bredspektret intravenøs antibiotika som dekker grampositive organismer og Hib, vanlige anbefalinger er tredjegenerasjons kefalosporiner eller amoksicillin/klavulinsyre (4-7, 11). Kortisonbehandling er omstridt, og det er ikke vist at det har effekt $(4,7,12)$. De fleste voksne kan klare seg uten intubering, men bør overvåkes nøye i sykehus med anestesiberedskap $(4,7,8,10,12-14)$. Det har vært forsøkt å finne prediktorer for alvorlig forløp som nødvendiggjør intubering, men slike har ikke entydig latt seg identifisere. Stridor er gjennomgående assosiert med at det kan bli nødvendig med luftveisintervensjon, mens man i enkeltstudier har funnet at behov for luftveisintervensjon også er assosiert med diabetes, pustebesvær, hypoksi, sikling, grøtet stemme, feber, rask forverring og at pasienten foretrekker å sitte i oppreist stilling $(4,5,7,12,13)$.

Ved mistanke om epiglottitt bør pasienten raskt legges inn i sykehus med anestesiberedskap og om mulig med øre-nese-halsavdeling. Intubering innebærer risiko for komplikasjoner og forverring av tilstanden og bør derfor gjøres i sykehus der komplikasjoner også kan håndteres $(7,13)$. Hvis en pasient utvikler luftveisobstruksjon utenfor sykehus og det er mistanke om epiglottitt, bør vedkommende ledsages til sykehus av 
personell med kompetanse $\mathrm{i}$ å sikre luftveier. I vårt tilfelle var det kort reisevei til nærmeste øre-nese-hals-avdeling, under ti minutter, og det å tilkalle anestesikyndig personale til legevakten ble vurdert å skape unødvendige forsinkelser.

Avhengig av pasientens respiratoriske besvær må anestesikyndig lege, om mulig i samråd med øre-nese-hals-lege, vurdere riktig metode for sikring av luftveier. Ved en truende luftveissituasjon forsøkes i første omgang konvensjonell intubering eller intubering via fleksibelt skop. Dersom situasjonen er svært kritisk og intubasjon ikke kan gjenomføres grunnet trange forhold, utføres nødtrakeotomi/koniotomi. En enkel og forholdvis sikker måte å gjøre koniotomi på er å bruke et ferdigmontert koniotomisett. Hvis man har god tid, kan konvensjonell trakeotomi i lokalbedøvelse være et alternativ. Enkelte erfarne halskirurger har i den akutte, kritiske situasjonen gått direkte for en konvensjonell trakeotomi, men dette kan ikke anbefales generelt, grunnet risiko for store blødninger.

Denne kasuistikken illustrerer at epiglottitt ikke er en utryddet sykdom. Det er viktig ikke å glemme denne differensialdiagnosen, da tilstanden kan utvikle seg svært raskt og bli livstruende. Kasuistikken viser hvor viktig det er å være årvåken, gjøre grundige undersøkelser og eventuelt rådføre seg med mer erfarne kolleger når pasientens plager ikke stemmer overens med vanlige tilstander.

Pasienten har gitt samtykke til at artikkelen blir publisert.

\section{Rebecca Bhatti (f. 1978)}

har jobbet ved Allmennlegevakten ved Legevakten i Oslo siden 2009. Hun har vært halvannet år som lege i spesialisering ved medisinsk avdeling ved Levanger sykehus.

Forfatter har fylt ut ICMJE-skjemaet og oppgir ingen interessekonflikter.

\section{Tone Solvik-Olsen (f. 1976)}

er lege i spesialisering ved barnemedisinsk avdeling ved Sykehuset Telemark. Hun har tidligere jobbet tre år ved Allmennlegevakten ved Legevakten i Oslo.

Forfatter har fylt ut ICMJE-skjemaet og oppgir ingen interessekonflikter.

\section{Karl Fredrik Nordfalk (f. 1976)}

er spesialist i øre-nese-hals-sykdommer og overlege ved Øre-nese-hals-avdelingen, Oslo universitetssykehus, Rikshospitalet. Han er opptatt i ph.d.-programmet ved Universitetet i Oslo og forsker på skader i balansesystemet etter cochleaimplantasjon.

Forfatter har fylt ut ICMJE-skjemaet og oppgir ingen interessekonflikter.

\section{Odd Martin Vallersnes (f. 1969)}

er spesialist i allmennmedisin og legeskiftleder ved Allmennlegevakten ved Legevakten i Oslo. Han er stipendiat ved Avdeling for allmennmedisin ved Universitetet i Oslo og forsker på behandling av akutte rusmiddelforgiftninger på legevaktnivå.

Forfatter har fylt ut ICMJE-skjemaet og oppgir ingen interessekonflikter.
Litteratur

1. Melbye H, Hjortdahl P, Langhammer A. Lunger og luftveier. I: Hunskår S, red. Allmennmedisin. 2. utg. Oslo: Gyldendal Akademisk, 2003: 135.

2. Norsk helseinformatikk. Difteri. http://nhi.no/ livsstil-og-helse/reisemedisin/sykdommer/ difteri-1740.html (7.2. 2012)

3. Folkehelseinstituttet. Barnevaksinasjonsprogram met. http://www.fhi.no/eway/default.aspx?pid= 233\&trg=Main Left 5631\&MainArea 5661 $=5631 \cdot 0$ 15,4537:1:0:0:0:0\&MainLeft_5631=5544:69485:1 5641:1:0:0 (7.2. 2012)

4. Mayo-Smith MF, Spinale JW, Donskey CJ et al. Acute epiglottitis. An 18-year experience in Rhode Island. Chest 1995; 108: 1640-7.

5. Bizaki AJ, Numminen J, Vasama JP et al. Acute supraglottitis in adults in Finland: review and analysis of 308 cases. Laryngoscope 2011: 121: 2107-13.

. Isakson M, Hugosson S. Acute epiglottitis: epidemiology and Streptococcus pneumoniae serotype distribution in adults. J Laryngol Otol 2011 125: $390-3$

7. Frantz TD, Rasgon BM, Quesenberry CP Jr. Acute epiglottitis in adults. Analysis of 129 cases. JAMA 1994: 272: 1358-60.

8. Briem B, Thorvardsson O, Petersen H. Acute epiglottitis in Iceland 1983-2005. Auris Nasus Larynx 2009: 36: 46-52.

9. McEwan J, Giridharan W, Clarke RW et al. Paediatric acute epiglottitis: not a disappearing entity Int J Pediatr Otorhinolaryngol 2003; 67: 317-21.

10. Price IM, Preyra I, Fernandes CM et al. Adult epiglottitis: a five-year retrospective chart review in a major urban centre. CJEM 2005; 7: 387-90.

11. Al-Qudah M, Shetty S, Alomari M et al. Acute adult supraglottitis: current management and treatment. South Med J 2010; 103: 800-4.

12. Katori H, Tsukuda M. Acute epiglottitis: analysis of factors associated with airway intervention. J Laryngol Otol 2005; 119: 967-72.

13. $\mathrm{Ng} \mathrm{HL}$, Sin LM, Li MF et al. Acute epiglottitis in adults: a retrospective review of 106 patients in Hong Kong. Emerg Med J 2008; 25: 253-5.

14. Park KW, Darvish A, Lowenstein E. Airway management for adult patients with acute epiglottitis: a 12-year experience at an academic medical center (1984-1995). Anesthesiology 1998; 88: 254-61.

\section{Et forbilledlig behandlingsløp - fordi det skjedde i Oslo sentrum?}

Epiglotitt er en sjelden sykdom. Hos voksne er sår hals og svelgevansker de vanligste symptomene. Bhatti og medarbeidere beskriver en tidligere frisk mann i 30-årene som under to timer etter at han oppsøkte legevakten ble overflyttet til universitetssykehus i ambulanse. Ved ankomst til akuttmottaket var han bevisstløs og ble nødtrakeotomert. Åtte dager senere ble han utskrevet.

I artikkelen beskrives et forbilledlig behandlingsforløp - som uten tvil berget pasientens liv. Det vil særlig være legevakttjenesten og fagområdene øre-nese-hals og anestesi som kan lære noe av denne kasuistikken. Kommentarene herunder vil knytte seg at hendelsen skjedde $i$ en by med universitetssykehus, ikke i deler av landet med andre geografiske forhold og helt andre for- utsetninger når det gjelder medisinsk kompetanse i tilstedevakt.

I tillegg til beslutningen om å overflytte pasienten til sykehus i tide var det særlig tre kritisk viktige faktorer som var helt avgjørende for utfallet i denne kasuistikken.

Transporttid. Blodgass ved ankomst sykehuset viste pH 6,6 (7,35-7,43). Det er derfor innlysende at pasienten overlevde fordi transporttiden fra legevakten til nærmeste ørenese-hals-avdeling var svært kort (under ti minutter).

Kompetanse. Tilstedeværelse av øre-nesehals-spesialist ved sykehuset den aktuelle natten var avgjørende for at pasienten fikk adekvat behandling. Selv ved universitetssykehusene vil det ikke alltid være øre-nesehals-spesialist som har tilstedevakt. Ved mel- lomstore sykehus med øre-nese-hals-avdeling vil det oftest være lege i spesialisering som har tilstedevakt, og her vil det som regel også være lege i spesialisering som har tilstedevakt $\mathrm{i}$ anestesiavdelingen. Ved sykehus uten øre-nese-hals-lege som tilstedevakt må man anta at anestesilegen vil spille en vesentlig rolle $\mathrm{i}$ håndteringen av tilfeller av «vanskelig luftvei». Ved disse sykehusene vil dette som regel være spesialist $\mathrm{i}$ anestesi. Disse har ofte ikke tilstedevakt.

Nødtrakeotomi. Etter mislykket intubasjonsforsøk av anestesilege og øre-nese-halsspesialist valgte sistnevnte å nødtrakeotomere. Dette berget pasientens liv. Omfanget av nødtrakeotomi i Norge er ukjent, men mest sannsynlig er det lavt. Trakeotomi har tradisjonelt vært øre-nese-hals-fagets domene, 